Michael Ulan is an econtemic analyst at the U.S. Department of State. Willian G. Dewold is director of research at the Federal Reserve Bank of 5t. Louis. James B. Bullard is a senion economist at the Federal Reserve Bank of St. Lovis. Jerram Betts provided research assistonce. Any views expressed in this article are those of the authors and not necessarily those of the U.S. Department of State, the Federal Reserve Bank of St. Loesis or the Federal Reserve System.

\section{U.S. Official Forecasts of G-7 Economies, 1976-90}

\section{Michael Ulan, William C. Dewald and James B. Bullard}

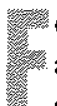
orecasts are regularly used in making fiscal and monetary policy decisions. For many decisionmakers, the likely short-term effect of a proposed action is a major concern in deciding whether to implement a particular policy. Such decisions are typically made in the context of considerable uncertainty, not only about what the likely effects of a particular action might be, but also about the momentum and direction of aggregate economic variables in themselves. Thus, an important concern from a policy point of view is the extent to which forecasts are reliable representations of economic outcomes at relatively short horizons, such as a year.

The purpose of this article is to report facts concerning the accuracy of the U.S. official forecasts of real output growth and inflation from 1976 to 1990 for the Group of Seven $(G-7)$ economies: Canada, France, Italy, Japan, the United Kingdom, the United States and West Germany. Though widely distributed within the government, the Administration forecasts had been classifled and not available to the public. We obtained the forecasts for years through 1990 under a Freedom of Information Act request with the helpful cooperation of the Treasury Department.

The accuracy of these forecasts is measured against the standard of actual real output growth and inflation as subsequently published in the Treasury's World Economic Outlook
(WEO). The Administration forecasts and their accuracy are reported along with a number of alternative forecasts. The primary comparison is to projections made for the G-7 by the Organization for Economic Cooperation and Development (OECD) and by Data Resources Incorporated (DRI). For the United States only, we also compare the Administration forecasts to those made by the Blue Chip consensus and the U.S. Federal Reserve "Greenbook." For each country and for the G-7 nations taken as a whole, the outlooks are evaluated on the basis of the differences between predictions and outcomes. The predictions and outcomes are expressed in terms of year-over-year percentage changes. The statistics cited are the sum of squared errors, the mean squared errors, the root mean squared errors (RMSE) and the bias (sum of prediction minus outcome). We think these measures provide simple but effective summary statistics useful in evaluating forecast accuracy.

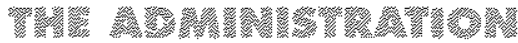

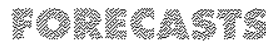

\section{Administrotion Forocests of Red Outpus Growh}

The errors in the Administration forecasts of real gross national product (GNP) (gross domestic product, GDP, in some cases) growth in the $G-7$ nations are shown in Figure 1. The summary statistics relating to the errors in these forecasts appear in Table 1. The sum of squared errors of the Administration's real output growth forecasts is largest for Canada, the United States and West Germany. Just under half of the forecast errors were of a different sign from the errors of the preceding year. The number of sign reversals of forecast error, not counting a zero error as a sign change, ranged from four for Japan to eight for the United States.

Like the other forecasters, the Administration simply missed the deep recessions in 1982 in the United States and Canada. The Administration forecasted 3.4 percent real

\footnotetext{
The Blwe Chip Economic Mditcatos newstetter is published monttly and suveys maiou forecosters of the U.S. econonity. The Federal Resenve "Greentooox" is a docament distributed to toptevel staff and Federal Open Marke Comnittee (FOHO) mentbers shortly before ead Fonc meeting. The FoMc is the pintary policynaking om of the Federd Reserve, Greenbook informention is dosstifed for five veas followisg end FOMC neeting.
} 


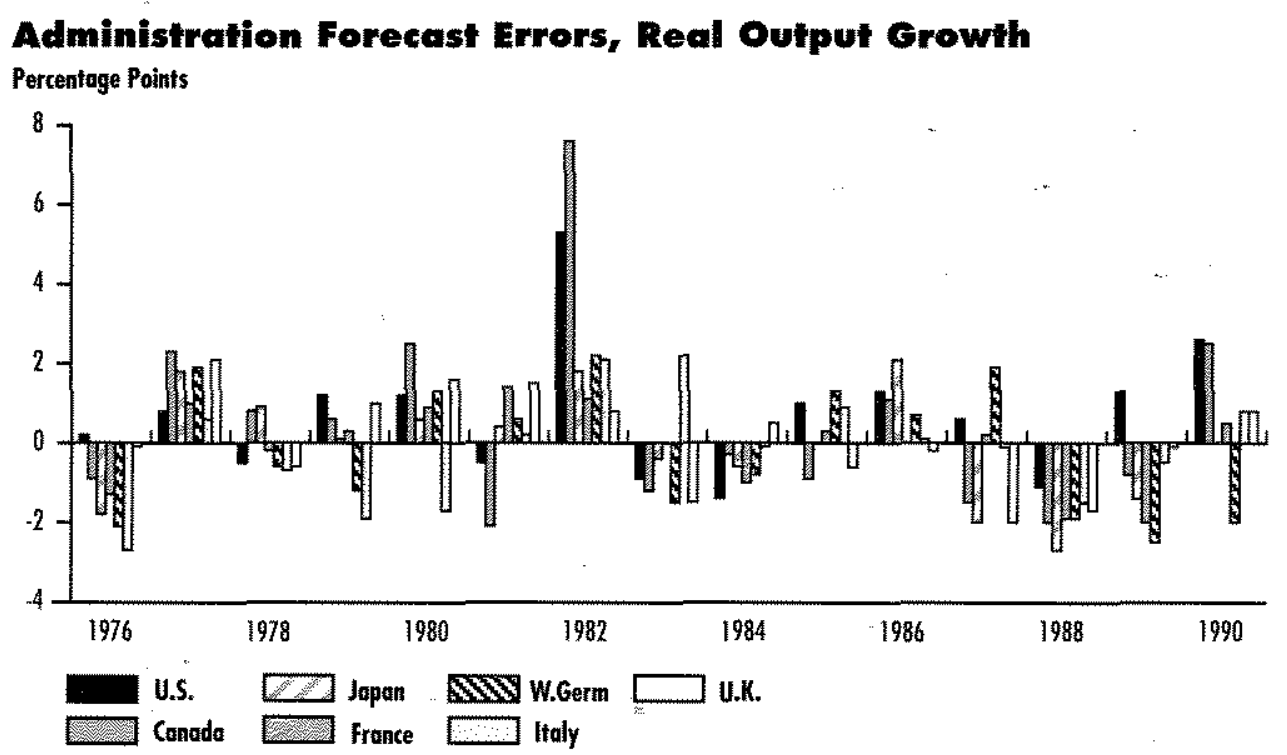

output growth for the United States in 1982 and 3.2 percent for Canada. The outcome was a 1.9 percent decrease in output in the United States and a 4.4 percent decrease in Canada, one of the deepest recessions in either country since the end of World War Il In absolute terms, the 1982 forecast errors for U.S. and Canadian economic growth were two-to-three times as large as any for a non-North American G-7 economy over the 15 years covered here, as all of the largest absolute forecast errors were between 2 percentage points and 3 percentage points for the remaining countries. While output fell in some other G-7 economies in 1982, other nations did not experience a comparable reversal of fortunes.

There were, however, some large declines in real output growth in other countries in other years. Italy, for instance, experienced a 4.2 percentage point fall in its output growth rate (from 4.0 percent to -0.2 percent) between 1980 and 1981, and the United Kingdom witnessed a 4.3 percentage point decline (from 1.5 percent to -2.8 percent) between 1979 and 1980 . Administration forecasts in these instances, however, were not so wide off the mark as for the U.S. and Canadian forecasts for 1982. Moreover, the error in the Administration's forecasts of real output

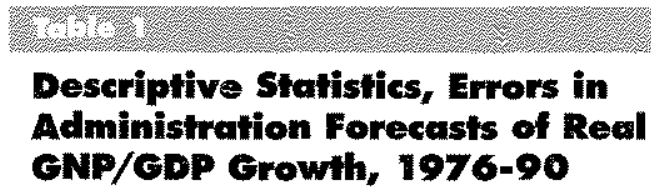

\begin{tabular}{|c|c|c|c|c|}
\hline Country & $\begin{array}{c}\text { Sun of } \\
\text { Squered } \\
\text { Errors }\end{array}$ & $\begin{array}{c}\text { Mean } \\
\text { Squared } \\
\text { Error } \\
\end{array}$ & RMSE & Bias \\
\hline Unted Stotes & 47.63 & 3.18 & 178 & 11.1 \\
\hline Condolo & 92.21 & 6.15 & 2.48 & 77 \\
\hline Japan : & 29.24 & 195 & 1.40 & -12 \\
\hline france & 15.79 & 105 & 1.03 & -07 \\
\hline West Germany & 39.25 & 262 & 1.62 & -27 \\
\hline Ifaly & 27.91 & 1.86 & 1.36 & -23 \\
\hline United Kingdom & 21.67 & 1.45 & 1.20 & 1.5 \\
\hline 6.7 total & 273.70 & 2.61 & 1.61 & 13.4 \\
\hline
\end{tabular}

growth in Italy and the United Kingdom was larger in non-turning-point years than during these turning-point episodes. In the case of Italy, the largest error was for 1976, when the nation's economy experienced a substantial upturn. In that year, the change in direction of the Italian economy (a total of 9.3 percentage points-from a decline of 3.7 percent in 1975 to output growth of 5.6 percent in 1976) was actually greater than the percentage point changes in the direction of real output growth in the U.S. and Canadian economies in 1982, 


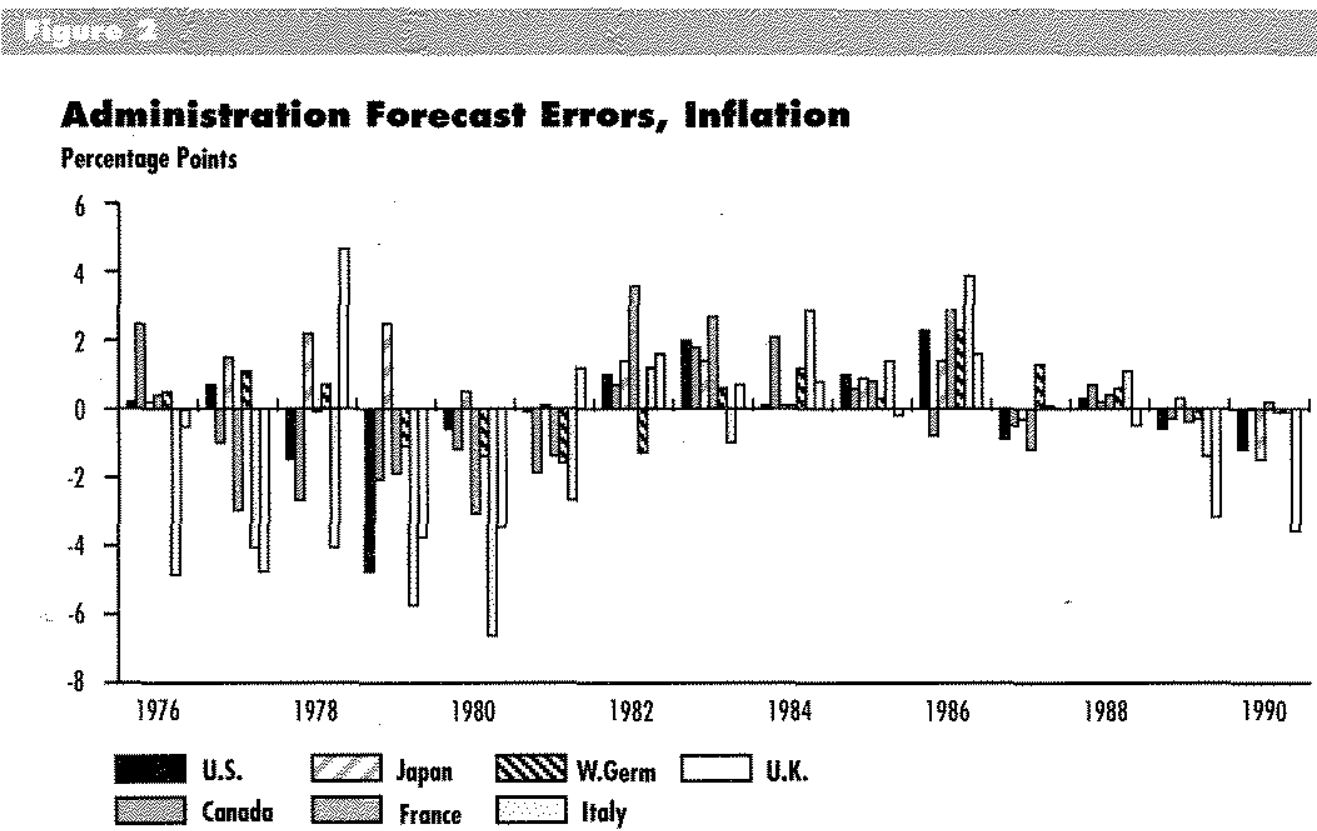

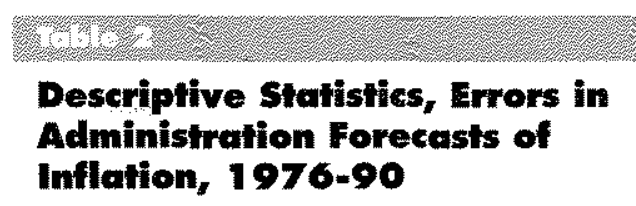

\begin{tabular}{|c|c|c|c|c|}
\hline Country & $\begin{array}{c}\text { Sum of } \\
\text { Squared } \\
\text { Crrors }\end{array}$ & $\begin{array}{l}\text { Mean } \\
\text { Squared } \\
\text { Effor }\end{array}$ & RMSE & Bias \\
\hline United States & 40.19 & 268 & 1.64 & -21 \\
\hline Canedo & 33.97 & 227 & 1.51 & -21 \\
\hline Japen & 2281 & 152 & 1.23 & 10.9 \\
\hline Frence: & & 370 & .92 & 0.0 \\
\hline West Gernany & & 125 & 1.12 & 2.8 \\
\hline Italy & 17465 & 11.64 & 341 & -20.3 \\
\hline Uniled Kringdon & 103.25 & 6.88 & 262 & -9.5 \\
\hline 67 otol $)$ & 449.03 & 4.28 & 2.07 & -20.3 \\
\hline
\end{tabular}

but the error in the Administration forecast of Italian real GDP growth in 1976 was only -2.7 percentage points.

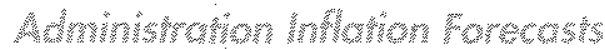

The Administration forecast errors for inflation from 1976 to 1990 in the G-7 nations are shown in Figure 2, while Table 2 presents the associated summary statistics. The Administration forecasts of U.S. inflation in 1980 pertained to the GNP deflator rather than the consumer price index (CPI).

Hence, for this year the forecast error is calculated with respect to the change in that measure rather than the CPI. The sum of squared errors is largest for Italy and the United Kingdom. The large error in the forecast of United Kingdom inflation in 1978 is attributable primarily to a decline in inflation in that year; inflation fell from 15.8 percent in 1977 to 8.3 percent in 1978 . It subsequently rebounded to 13.4 percent in 1979. During 1978 , there were price controls in force on some components of the CPI market basket and, at government urging, unions moderated their wage demands. In 1979 , with the election of a Conservative government, the unions returned to no-holds-barred wage bargaining, and the government not only removed price controls but also increased the rate of value-added tax applicable to several items in the CPI market basket, boosting inflation during that year.

As Table 2 reveals, the Administration tended to underpredict inflation in Italy and the United Kingdom, countries with high average inflation rates, and to overpredict inflation in West Germany and Japan, countries with comparatively low inflation. Errors in one direction were followed by errors in the other direction about a third of the time- 
less than was the case for real output growth. The number of reversals of sign of the forecast error ranged from three for Japan and West Germany to six for both France and the United Kingdom, again, not including a zero error as a change in sign.

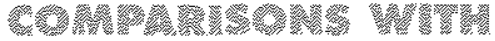

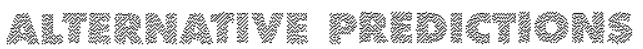

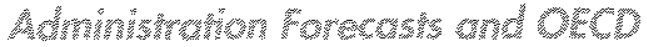

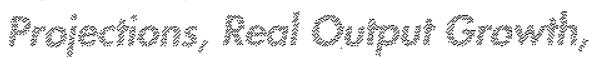 Whar}

The OECD's projections of economic growth for G-7 nations between 1976 and 1990 are readily available for comparison with the Administration predictions. ${ }^{2}$ The OECD staff issues its projections in the Economic Outlook twice each year-around mid-year and in December. We compared the December OECD projections (prepared in mid-November) with Administration forecasts, although the latter were generally made earlier. Summary statistics covering the Administration's predictions and OECD projections over 1976-90 appear in Table 3.

The OECD makes several assumptions about members' economies in projecting each nation's economic growth. The organization assumes that the exchange rate of the nation's currency during a year remains at the level of November in the previous year (the month the projections were prepared), that fiscal policy will remain unchanged and that the price of oil relative to that of OECD exports of manufactures will remain constant. The reasoning behind these assumptions is that the OECD is "advising" its member governments where they are headed economically if they continue to pursue current policies, not taking into account prospective changes in policies. Hence, the OECD considers its product a projection rather than a forecast.

Table 3 shows that, for each $G-7$ nation except Italy, the sum of squared errors of the OECD real growth projection is smaller than

${ }^{2}$ Since the $0 \mathrm{ECD}$ uses the persend consumption deflator rather thon the $\mathrm{CP}$ as its measure of inflation, iss inflation projections ore not consicered here. that for the Administration's forecast errors,

For both the OECD and the Administration, the smallest sum of squared errors was achieved in the case of France, while the country evidently posing the most difficulty over this period was

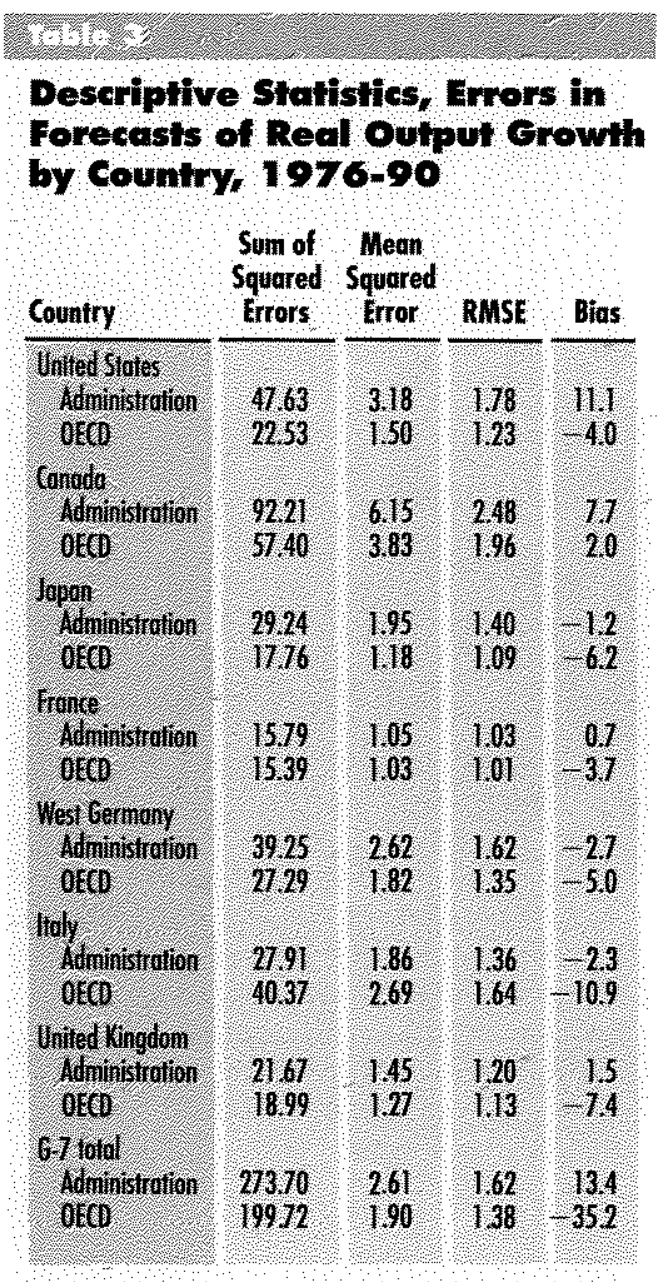

Canada. For the Administration, the second worst case was the United States.

To what might one attribute the generally greater accuracy of the OECD projections compared with the Administration's forecasts? One factor might be that OECD projections of real output growth in the $G-7$ nations were made closer to the beginning of the forecast year. The OECD might also be in a better position to closely follow the economic performance of many nations by evaluating worldwide influences than is the Administration, whose forecasts are largely dependent on inputs from individual countries. On the other hand, the OECD procedure simply assumes unchanged fiscal policies, exchange rates and real oil prices. These might be factors that would lead to less accuracy in their projections to the extent that such factors have a predictable effect on real output growth. 


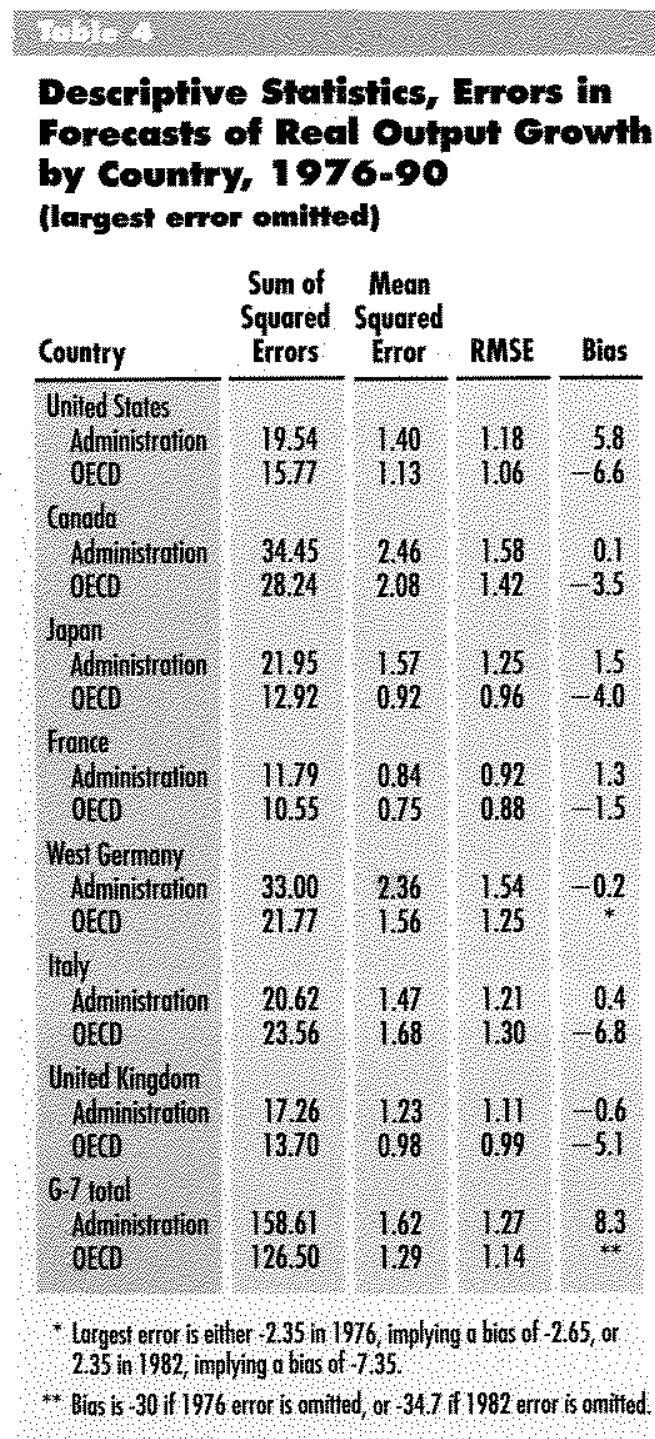

Both the Administration forecasts and the $O E C D$ projections of real growth display bias, according to our measure-but in opposite directions. The Administration's real output growth forecasts in total are biased upward, with the main contributors to the total being the errors associated with the United States and Canada. In contrast, except for Canadian economic growth, the OECD projections are biased downwardsubstantially for the cases of Italy and the United Kingdom.

Since one large error can mar an otherwise good performance, we also examined the data with the largest error omitted; the descriptive statistics are presented in Table 4.
With one observation deleted, the sum of squared errors of both the Administration. and $O E C D$ forecasts tend to be much smaller and much the same.

Our data set contained complete DRI forecasts of economic growth and inflation for all the G-7 countries for the period of 1983 to 1990 . The summary statistics pertaining to these DRI forecasts are compared with those of the Administration and the OECD over the same period in Tables 5 and 6 . Save for the real growth forecasts for Italy, Japan and the United States, the DRI forecasts over this evaluation period were more accurate than either the Administration forecasts or the OECD projections. DRI was also more accurate than the Administration in forecasting inflation for every country except Japan during this period.

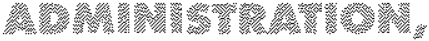

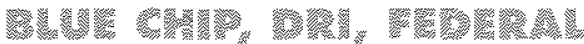

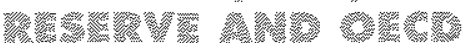

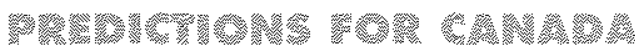

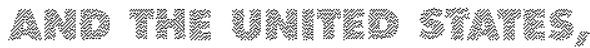

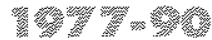

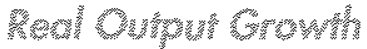

The Blue Chip Economic Indicators consensus forecast of year-over-year real economic growth in the United States has been published monthly since 1976 (first forecasting 1977). A consensus forecast of the year-over-year change in the CPI has been published since 1979 (forecasting 1980). Both the number and the identities of participating private-sector forecasters have changed over time. Thotugh DRI, OECD and Federal Reserve Greenbook forecasts for the United States are available for the full period for which we have Administration forecasts, we only compared the five forecasting records for the period for which the Blue Chip consensus has been available. As shown in Table 7, the Blue Chip, DRI, Federal Reserve and OECD projections of U.S. economic growth were each more accurate than the Administration forecasts over this period, with the OECD achieving the greatest overall accuracy. The Administration forecasts for Canadian real output growth 


\begin{tabular}{|c|c|c|c|c|}
\hline \multicolumn{5}{|c|}{$\begin{array}{l}\text { Descriptive Shatisties, Errors in } \\
\text { Forecasts of Real Oufput Growt } \\
\text { by Country, 1983-90 }\end{array}$} \\
\hline Country & $\begin{array}{c}\text { Sun of } \\
\text { Squared } \\
\text { Errors }\end{array}$ & $\begin{array}{c}\text { Mean } \\
\text { Squared } \\
\text { Error }\end{array}$ & RMSE & Bies \\
\hline $\begin{array}{l}\text { United States } \\
\text { Administrafion } \\
\text { DRI } \\
\text { OECO }\end{array}$ & $\begin{array}{l}15.48 \\
17.08 \\
17.53\end{array}$ & $\begin{array}{l}194 \\
2.14 \\
2.19\end{array}$ & $\begin{array}{l}139 \\
1.46 \\
1.48\end{array}$ & $\begin{array}{r}3.4 \\
5.4 \\
-17\end{array}$ \\
\hline 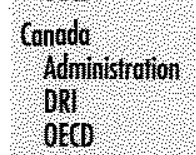 & $\begin{array}{l}16.69 \\
16.56 \\
18.74\end{array}$ & $\begin{array}{l}209 \\
207 \\
2.34\end{array}$ & $\begin{array}{l}1.44 \\
1.44 \\
153\end{array}$ & $\begin{array}{r}-3.6 \\
-5.6 \\
-4.5\end{array}$ \\
\hline $\begin{array}{l}\text { Iopon } \\
\text { Adrinistodion } \\
\text { ORI } \\
\text { OECO }\end{array}$ & $\begin{array}{l}18,18 \\
12 \% 6 \\
1107\end{array}$ & $\begin{array}{l}2.27 \\
1.62 \\
1.38\end{array}$ & $\begin{array}{l}1.51 \\
1.27 \\
1.18\end{array}$ & $\begin{array}{r}-5.0 \\
-7.8 \\
-4.5\end{array}$ \\
\hline $\begin{array}{l}\text { France } \\
\text { Adninistrafion } \\
\text { ORI } \\
\text { OECO }\end{array}$ & $\begin{array}{l}8.99 \\
5.86 \\
8.92\end{array}$ & $\begin{array}{l}1,12 \\
0.73 \\
1.12\end{array}$ & $\begin{array}{l}1.06 \\
086 \\
106\end{array}$ & $\begin{array}{r}-3.9 \\
-3.0 \\
-3.3\end{array}$ \\
\hline $\begin{array}{l}\text { West Germony } \\
\text { Addinistrotion } \\
\text { ORl } \\
\text { OECO }\end{array}$ & $\begin{array}{l}22.54 \\
10.07 \\
14.86\end{array}$ & $\begin{array}{l}282 \\
1.26 \\
1.86\end{array}$ & $\begin{array}{l}1.68 \\
1.12 \\
1.36\end{array}$ & $\begin{array}{r}4.8 \\
4.5 \\
-5.5\end{array}$ \\
\hline $\begin{array}{l}\text { laly } \\
\text { idministiofion } \\
\text { OEI } \\
\text { OECO }\end{array}$ & $\begin{array}{r}8.82 \\
0.47 \\
7.25\end{array}$ & $\begin{array}{l}110 \\
0.31 \\
0.91\end{array}$ & $\begin{array}{l}1.05 \\
0.95 \\
0.95\end{array}$ & $\begin{array}{l}1.8 \\
07 \\
0.2\end{array}$ \\
\hline $\begin{array}{l}\text { Unifed Kingdom } \\
\text { adminitistadion } \\
\text { ORI } \\
\text { OECO }\end{array}$ & $\begin{array}{r}10.44 \\
6.31 \\
11.20\end{array}$ & $\begin{array}{l}1.31 \\
0.79 \\
1.40\end{array}$ & $\begin{array}{r}1.14 \\
0.89 \\
1.83\end{array}$ & $\begin{array}{r}-4.0 \\
-5.1 \\
-5.1\end{array}$ \\
\hline $\begin{array}{l}\text { G.7 otol, } \\
\text { Administration } \\
\text { ORI: } \\
\text { OECD }\end{array}$ & $\begin{array}{r}101.14 \\
79.31 \\
89.57\end{array}$ & $\begin{array}{l}1,81 \\
1.42 \\
1.60\end{array}$ & $\begin{array}{l}1.34 \\
1.19 \\
1.27\end{array}$ & $\begin{array}{r}-16.4 \\
-30.7 \\
-24.3\end{array}$ \\
\hline
\end{tabular}

were less accurate than those of either DRI or the OECD.

For U.S. economic growth, there was a "rosy scenario" positive bias of the Administration forecasts which was approached in magnitude only by the negative bias of the Federal Reserve forecasts. As noted in the previous section, the exclusion of the obser vation for 1982 greatly improves the accuracy of the Administration forecasts. In fact, the same observation accounted for the greatest error in the forecasts of the Administration, the Blue Chip consensus and DRI. In September 1981, many forecasters predicted

\begin{tabular}{|c|c|c|c|c|}
\hline \multicolumn{5}{|c|}{$\begin{array}{l}\text { Deseriptive Statisties, Errors in } \\
\text { Forecasts of Inflation by } \\
\text { Country, } 1983-90\end{array}$} \\
\hline Country & $\begin{array}{l}\text { Sum of } \\
\text { Squared } \\
\text { Errors }\end{array}$ & $\begin{array}{c}\text { Mean } \\
\text { Squared } \\
\text { Error }\end{array}$ & RMSE & Bias \\
\hline $\begin{array}{l}\text { United Stutes } \\
\text { Administration } \\
\text { ORII }\end{array}$ & $\begin{array}{r}13.00 \\
9.16\end{array}$ & $\begin{array}{l}1.63 \\
1.15\end{array}$ & $\begin{array}{l}1.28 \\
1.07\end{array}$ & $\begin{array}{l}3.0 \\
28\end{array}$ \\
\hline $\begin{array}{l}\text { Congdo: } \\
\text { Adninistration } \\
\text { ORI }\end{array}$ & $\frac{9.48}{4.61}$ & $\begin{array}{l}1.19 \\
0.58\end{array}$ & 0.09 & $\begin{array}{l}3.6 \\
27\end{array}$ \\
\hline $\begin{array}{l}\text { lapan } \\
\text { Aluninistrotion } \\
\text { ORI }\end{array}$ & $\begin{array}{l}7.21 \\
12.78\end{array}$ & $\begin{array}{l}0.90 \\
1.60\end{array}$ & $\begin{array}{l}0.95 \\
1.26\end{array}$ & $\begin{array}{r}2.5 \\
-0.2\end{array}$ \\
\hline $\begin{array}{l}\text { france } \\
\text { fdministration } \\
\text { Del }\end{array}$ & $\begin{array}{l}18.15 \\
877\end{array}$ & $\begin{array}{l}2.27 \\
1.10\end{array}$ & 1.51 & $\begin{array}{l}55 \\
53\end{array}$ \\
\hline $\begin{array}{l}\text { West Germany } \\
\text { Adnitistration } \\
\text { DRI }\end{array}$ & $\begin{array}{r}9.33 \\
8.89\end{array}$ & $\begin{array}{l}1,17 \\
1,11\end{array}$ & $\begin{array}{l}1.08 \\
1.05\end{array}$ & $\begin{array}{l}5.9 \\
5.3\end{array}$ \\
\hline $\begin{array}{l}\text { llaly Administration } \\
\text { oRl } \\
\text { ORl }\end{array}$ & $\begin{array}{l}2976 \\
11.46\end{array}$ & $\begin{array}{l}3.72 \\
1.43\end{array}$ & 1.93 & $\begin{array}{r}6.8 \\
3.6\end{array}$ \\
\hline $\begin{array}{l}\text { United Kingdont } \\
\text { Administrafion } \\
\text { DRI }\end{array}$ & $\begin{array}{l}27.18 \\
18.32\end{array}$ & $\begin{array}{l}3.39 \\
2.29\end{array}$ & $\begin{array}{l}1.84 \\
1.51\end{array}$ & $\begin{array}{r}-4.4 \\
-20\end{array}$ \\
\hline $\begin{array}{l}\text { G7 t tolal } \\
\text { Administration } \\
\text { DRI }\end{array}$ & $\begin{array}{r}114.11 \\
13.99\end{array}$ & $\begin{array}{l}2.04 \\
1: 32\end{array}$ & $\begin{array}{l}1.43 \\
1.15\end{array}$ & 22.9 \\
\hline
\end{tabular}

positive economic growth for the U.S, economy in 1982 even though it was already several months into a recession that would not bottom out for 14 months. The Greenbook and OECD forecasts, both of which, it is important to add, were made later in the year, were considerably better, predicting -0.6 and -0.5 , respectively, versus an actual outcome of -1.9 .

Table 8 shows the effects of omitting the largest error in computing the accuracy of these forecasts. The errors in the Administration, Blue Chip, DRI, Federal Reserve and OECD projections of U.S. real output growth for 1982 were $5.3,4.5,4.3,1.3$ and 1.4 percentage points, respectively. The largest Federal Reserve error was 2.5 , recorded in 1981, while the largest OECD error was 2.6, recorded in 1990 . The largest errors in the Administration, OECD and DRI forecasts of Canadian real output growth were $7.6,5.4$ and 


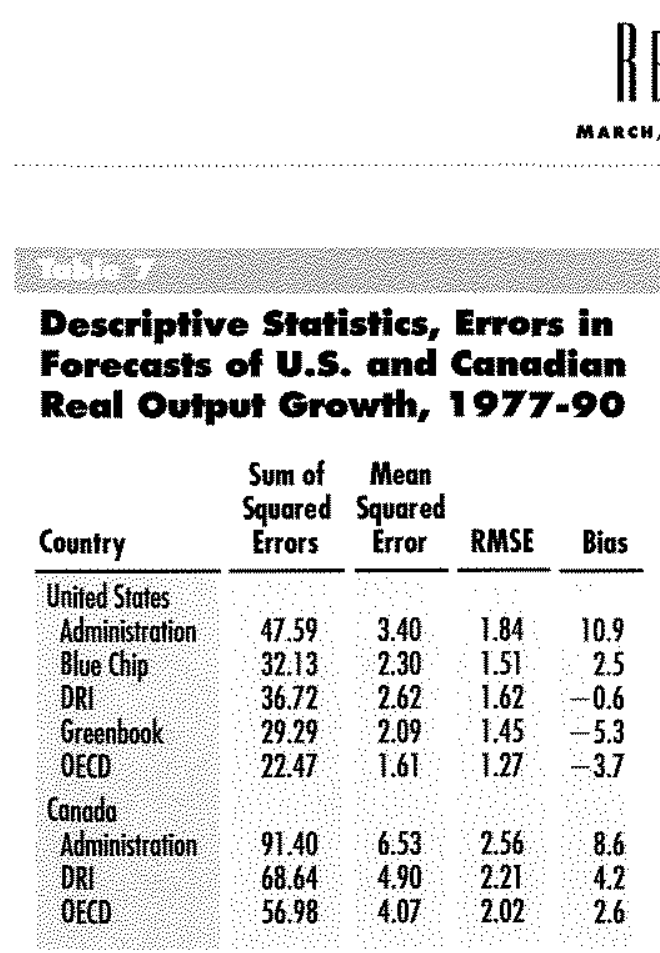

6.5 percentage points, respectively. With the largest error omitted, the Blue Chip consensus ranks first in accuracy for the United States.

\section{Wotur}

As shown in Table 9, in contrast to the situation with:respect to real outpul growth, the Administration was a marginally more accurate forecaster of U.S. inflation over the period 1980-90 than the Greenbook and also more accurate than the Blue Chip survey. DRI was the most accurate overall for the United States, and DRI also predicted Canadian inflation more accurately than the Administration. Summary statistics with the largest forecast error omitted are presented in Table 10. In this case, the Administration forecasts hold up very well against those of the other forecasters for the United States, as do DRI's inflation forecasts for Canada.

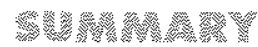

Comparing Administration forecasts to Blue Chip consensus, DRI, Federal Reserve Greenbook and OECD predictions of real output growth in the U.S. economy, we find that the Administration tended to see the future more optimistically and less accurately than the other forecasters. Much, though not all, of that rosy perspective was connected with the failure of the Administration to

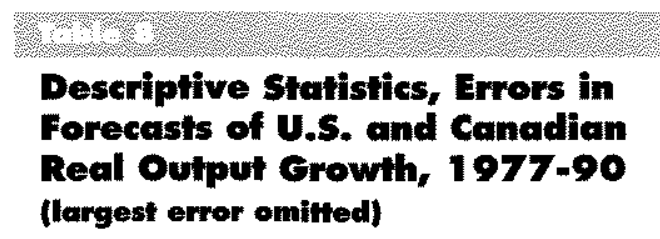

\begin{tabular}{|c|c|c|c|c|}
\hline Country & $\begin{array}{l}\text { Sum of } \\
\text { Squared } \\
\text { Errors }\end{array}$ & $\begin{array}{l}\text { Mean } \\
\text { Squared } \\
\text { Error }\end{array}$ & RMSE & Bitas \\
\hline \multicolumn{5}{|l|}{ United Stotes } \\
\hline Aduministrotion & 1950 & 1.50 & 1.23 & 5.6 \\
\hline blue diip & 11.38 & 0.89 & $0.94:$ & -2.0 \\
\hline $\mathrm{nt}$ & 18.23 & 1.40 & 1.18 & -49 \\
\hline Greentook & 2304 & 177 & 133 & -2.8 \\
\hline OECO & 1571 & 121 & 110 & -6.3 \\
\hline \multicolumn{5}{|l|}{ Conodo } \\
\hline AdnIIistrotion & 33,64 & 259 & 1.61 & 10 \\
\hline OBI & 2639 & 2.03 & 1,43 & -23 \\
\hline OEC) & 2782 & 2.14 & 146 & -28 \\
\hline
\end{tabular}

forecast the output decline in 1982. Deleting that observation substantially enhances measured forecast accuracy, reducing the RMSE from 1.78 to 1.18 over the 1976 to 1990 period. U.S. official forecasts were better with respect to inflation, as the Administration was one of the best among those compared in forecasting U.S. CPI inflation between 1980 and 1990

The Administration's forecasts of economic growth for almost all $G-7$ countries were less accurate than the $O E C D$ projections for the period 1976 to 1990 . The biases in the Administrations forecasts tend to be positive; those in the forecasts of U.S. and Canadian real output growth are particularly large. The biases in the OECD projections tend to be negative; those associated with projections of Italian and U.K. real output growth are large. For the $G-7$ as a whole, the projections of the OECD are much more accurate than those of the Administration. Over the 1983 to 1990 period, DRI was more accurate than either the Administration or the OECD for four of the G-7 countries.

The differences between the forecast errors of the Administration and the forecast (or projection) errors of the other forecasters may arise from differences in the times at which the forecasts or projections were prepared, a situation that may have influenced the quality of the historical baseline available to forecasters and the values of exogenous 


\section{2. \\ Descriptive Statistics, Errors in
Forecasts of U.S. and Canadion
Inflation, $1980-90$}

\begin{tabular}{|c|c|c|c|c|}
\hline Counity & $\begin{array}{c}\text { Sum of } \\
\text { Squered } \\
\text { Errors }\end{array}$ & $\begin{array}{l}\text { Mean } \\
\text { Squared } \\
\text { Errer }\end{array}$ & RMSE & Bias \\
\hline 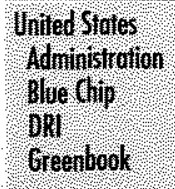 & & $\begin{array}{l}131 \\
1,58 \\
11.45\end{array}$ & $\begin{array}{r}114 \\
126 \\
109\end{array}$ & $\begin{array}{r}33 \\
6.4 \\
5,2\end{array}$ \\
\hline 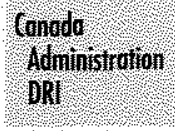 & $\begin{array}{l}1502 \\
1106\end{array}$ & $\begin{array}{l}1,37 \\
101\end{array}$ & 100 & $\begin{array}{l}12 \\
114\end{array}$ \\
\hline
\end{tabular}

variables assumed in predicting the future paths of the economies. Nonetheless, so far as we can ascertain, every forecast we have evaluated was a genuine prognostication of

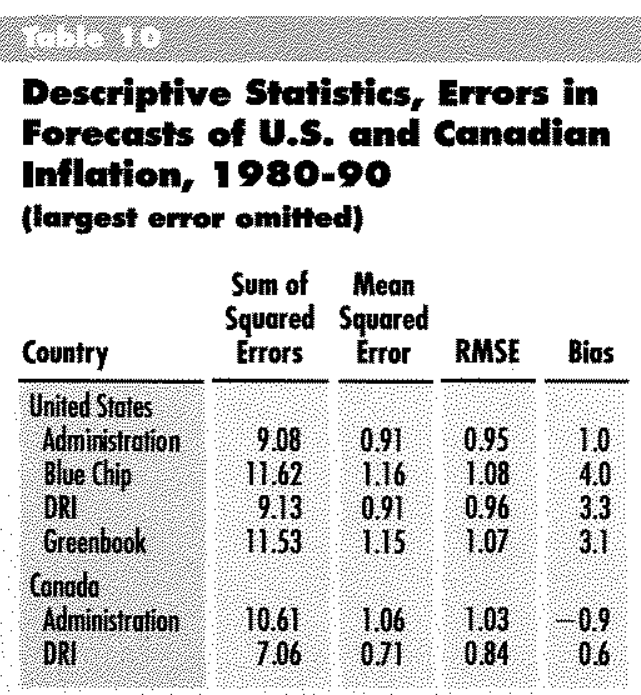

economic growth and inflation made in the closing months of a year with respect to the next year.

\section{$\sqrt{2}+1$}

\section{DATA SOURCES}

The Tecosury thought the Counciss fosecest of U.S. economic growtt in 1983 was too high and substituted the Blue Chip consensus foreccist. (As it tuned out, the Treasury-m that is, Blue Chip-forecast was also too high, but not so high os the Colned's?

${ }^{2}$ The dates of the Adriteistrotion forecasts for the next year range fom Septenber thisough December of the previous year.
The data used in this article come primarily from the World Economic Outlook (WEO) prepared by the United States Department of the Treasury, Blue Chip Economic Indicators, DRl's various Reviews, the OECD Economic Outlook and the Federal Reserve's Greenbook. The Administration forecasts of G-7 nations' economic growth and inflation have been made since 1975 (for 1976). The forecasts evaluated in this article cover 1976 to 1990 , the last year for which forecasts have been cleared by the Treasury for release to the public. This is also the last year for which the Greenbook forecasts are cleared for public release. With one major exception, the Administration forecasts for the U.S. economy are those of the Council of Economic Advisers.' Forecasts for the other $\mathrm{G}-7$ economies are produced by Treasury financial attachés at U.S, embassies in the capitals of these nations. The attachés review the host-government and host-country private-sector forecasts for the economies of the nations to which they are posted and base their own forecasts on such information, together with their own judgments about the national economies. The Blue Chip consensus forecasts are the mean values of the forecasts of the firms covered in the Blue Chip surveys. The DRI forecasts are based on the outputs of the DRI model and the judgments of that firm's staff. The OECD projections are prepared by members of that organization's staff. The Federal Reserve forecasts are prepared by the staff of the Federal Reserve Board.

The Administration, Blue Chip, DRI and Federal Reserve forecasts, and the OECD outlooks have appeared several times each year and are frequently revised. The WEO forecasts evaluated in this article are the last predictions of both economic growth and inflation for the next year made during the previous year. ${ }^{2}$ The Bhe Chip and DRI forecasts for the U.S. and Canadian economies selected for comparison to the Administration forecasts were those published during the same months as the Administration forecasts. The DRI forecasts begin with those for 1976 and run through those for 1990. A complete set of DRI forecasts for all of the G-7 countries 


\section{REVIEW \\ MARCH/APRIL 1905}

is available for each year since 1983 . The OECD projections are those published in December for the next year, beginning with the outlook for 1976. The Federal Reserve forecasts are those associated with the last Greenbook issued in a given calendar year (usually December).

GNP and GDP data are frequently revised. It was necessary to choose a fixed target to which to compare the forecasts. We used the Treasury Department's historical data, which it provided along with its forecasts in each issue of the WEO. Generally, historical data on GNP or GNP changes for a particular year continue to appear in the WEO for about
18 months following the end of that year. The last historical citation of the annual change in national GNP or GDP appearing in the WEO is the outcome to which the forecasts are compared. Although CPI data tend not to be revised after they are issued, a similar procedure has been followed in selecting the inflation data with which to compare the forecasts. Because the Treasury presents no bistorical data for growth or inflation in 1978 , we have compared its forecasts for 1978 with outcomes taken from the 1981 International Financial Statistics (IFS) yearbook."

\footnotetext{
${ }^{3}$ In 1986 , Canada changed the emphosis in its Notiond Income and Product Accounts (NAPA) fom GAP to GDP and stopped explicitly reporting historical seal GMP dota in its official bulletin, Notional income and Expenditure Accounts (NEA). When the Cangdion NIPA focas shifted, the Adninistofotion begal to forecost GIP insted of GAP for Conedo ond reported historicol GDP toto in the WFO. Since the 1985 and 1986 grawth forectasts for Conodo prepered by the

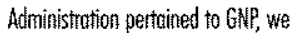
obtained ted GNP growth dom for 1985 and 1986 with which to conspure the forecosts.

${ }^{4}$ The Adrninistration's 1980 inftation forecos: for the United States, which oppeared in the September 1979 Woo, pertained to the Gip deflator rother then the $\mathrm{CPI}$. The deflator calculated on the basis of doto appenrifg in the 198 ifS yeorbook wos used to test the accurocy of this forecast. Given the Administation dotu, the September 1979 Blue Gíp; Del ond Federal Reserve forecusts of the increase in the U.S. GNP deflotor-rather Hon CPI inflation-ate erraloyed in this compurison
} 